\title{
Giant plexiform neurofibroma causing asymptomatic cervical spinal cord compression in a child with neurofibromatosis type 1
}

\author{
Jeffrey J Gold, ${ }^{1}$ Michael L Levy, ${ }^{2}$ John Ross Crawford ${ }^{3}$
}

${ }^{1}$ Department of Neurosciences, University of California San Diego, San Diego, California, USA

${ }^{2}$ Department of Neurosurgery, University of California San Diego, San Diego, California, USA

${ }^{3}$ Department of Neurosciences and Pediatrics, University of California San Diego, San Diego, California, USA

Correspondence to Dr John Ross Crawford, jrcrawford@ucsd.edu
To cite: Gold JJ, Levy ML, Crawford JR. BMJ Case Rep Published online: [please include Day Month Year] doi:10.1136/bcr-2013009799

\section{DESCRIPTION}

A 12-year-old boy with neurofibromatosis type 1 (NF-1) presented with a giant mass involving the posterior head and neck. The mass was present since 6 months of age and showed considerable growth over the past 2 years that caused extensive disfigurement that was deemed inoperable due to its size prior to immigration to USA. Physical examination revealed neurocutaneous findings consistent with NF-1. Neurological examination including mental status, cranial nerves, motor, sensory, reflex, coordination and gait examination was normal. MRI revealed a giant mass of the right scalp, neck, chest wall, axilla and mediastinum (figure 1). The mass had both extradural and intradural components that caused significant compression of the cervical spinal cord. MRI of the brain revealed minimal abnormalities associated with myelin vacuolisation of the globus pallidus and thalami. A subtotal resection was performed to relieve cord compression and pathology was consistent with a plexiform neurofibroma. Postoperatively, the patient had minor right arm weakness that resolved during the 4 month follow-up. Plexiform neurofibromas are commonly associated with NF-1 and routine MRI spine screening is controversial in asymptomatic patients. ${ }^{1}$ However, plexiform neurofibromas can be associated with symptomatic spinal cord compression. ${ }^{2}$ Our case highlights the invasive potential of plexiform neurofibromas in children diagnosed with NF-1.

\section{Learning points}

Neurofibromas are a diverse set of nerve sheath tumours of cutaneous, intraneural, plexiform and soft tissue varieties that can traverse the dura to become intraspinal and intracranial.

- Paediatric spinal cord tumours may be associated with significant spinal cord compression in the absence of symptoms and a normal neurological examination

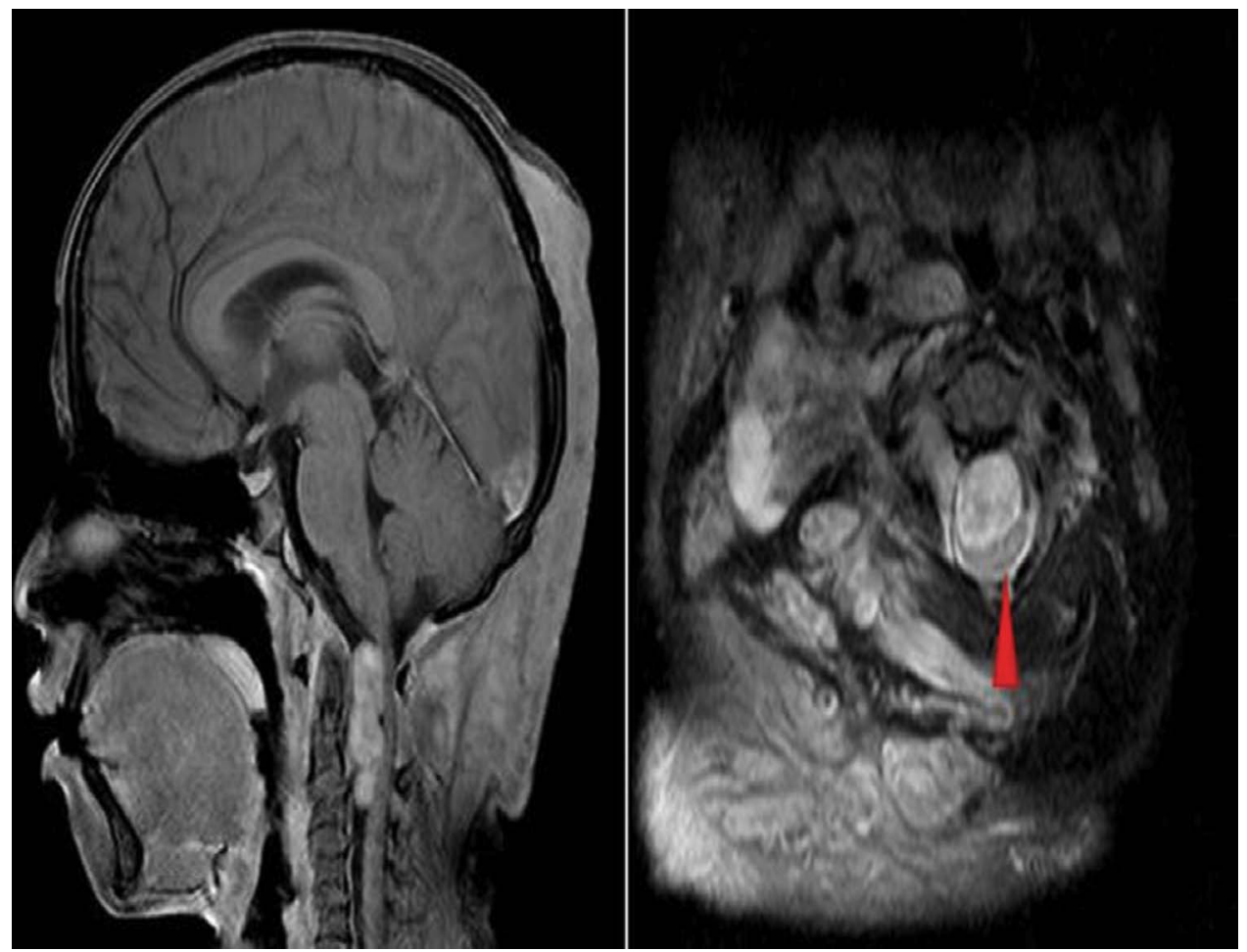

Figure 1 Post gadolinium T1-weighted MRI axial sequence on the left reveals the giant enhancing plexiform neurofibroma with the associated compression of the cervical spinal cord. The axial T2 MRI on the right demonstrates the extradural invasion of the tumour through the neuroforamina leading to significant cord compression (red arrowhead). 
Contributors JJG, MLL and JRC played an equal role in the case report design, writing and interpretation of the data. Each author has approved the final manuscript in its current form.

Competing interests None.

Patient consent Obtained.

Provenance and peer review Not commissioned; externally peer reviewed.

\section{REFERENCES}

1 Thakkar SD, Feigen U, Mautner VF. Spinal tumors in neurofibromatosis type 1: an MRI study of frequency, multiplicity and variety. Neuroradiology 1999;625-9.

2 Leonard JR, Ferner RE, Gutmann DH. Cervical cord compression from plexiform neurofibromas in neurofibromatosis 1. J Neurol Neurosurg Psychiatry 2007;1404-6.

Copyright 2013 BMJ Publishing Group. All rights reserved. For permission to reuse any of this content visit http://group.bmj.com/group/rights-licensing/permissions.

BMJ Case Report Fellows may re-use this article for personal use and teaching without any further permission.

Become a Fellow of BMJ Case Reports today and you can:

- Submit as many cases as you like

- Enjoy fast sympathetic peer review and rapid publication of accepted articles

- Access all the published articles

- Re-use any of the published material for personal use and teaching without further permission

For information on Institutional Fellowships contact consortiasales@bmjgroup.com

Visit casereports.bmj.com for more articles like this and to become a Fellow 